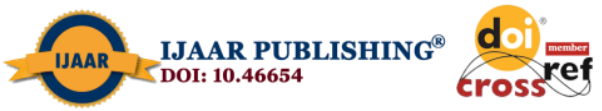

International Journal of Advanced Academic Research (Arts, Humanities and Education) | ISSN: 2488-9849

Vol. 6, Issue 8 (August, 2020)|www.ijaar.org

Journal DOI: 10.46654/ij.24889849

Article DOI: 10.46654/ij.24889849.a688

\title{
EDUCATORS' COMPETENCE AND UTILIZATION OF SOCIAL MEDIA IN SCIENCE TEACHER EDUCATION
}

\author{
${ }^{1}$ Nwoke Bright Ihechukwu, Ph.D, ${ }^{2}$ Ikwuanusi Eucharia Ndidi, Ph.D \& ${ }^{3}$ Rosemary Onuoha \\ ${ }^{1}$ Department of Mathematics \\ ${ }^{2,3}$ Department of Integrated Science \\ Alvan Ikoku Federal College of Education, Owerri, Imo State, Nigeria. \\ Email: bright.nwoke@alvanikoku.edu.ng
}

\begin{abstract}
The study investigated Educators' competence and utilization of social media in science teacher education. The study was carried out in Alvan Ikoku Federal College of Education, Owerri, Imo state. Based on the purpose of the study, 2 research questions guided the study. The population of the study consists of all the Educators in school of science of the Institution. Based on the size of the population of the educators in school of science, they were all used as sample for the study. The descriptive survey research design was adopted in carrying out the study. The instrument for data collection was a researcher made likert 4-point type questionnaire titled "Educators Competence and Utilization of Social Media (ECUSM)". The instrument had reliability coefficient of 0.83 determined using the Pearson's Product Moments Correlation Coefficient formula. The instrument was administered to the respondents on face-to-face basis by the researcher. The result of the study revealed that the educators were competent on the use of social media for personal purposes. Social media platforms were not utilized for academic purposes in the training of trainee teachers. Based on the result it was recommended that teacher educators should be trained on the utilization of social media in teacher training process through seminars, workshops and conferences.
\end{abstract}

Keywords: Educators, competence, Utilization, Social Media, Science Teacher Education. 


\section{Introduction}

Teacher education is tailored towards training of individuals who will in turn take up the teaching profession at all level of education. Those in the field of science are therefore trained to handle teaching of sciences applying appropriate and acceptable approaches. Teaching generally has become very complex as a result of the dynamic nature of the society and the usual traditional approach of teaching can no longer produce individuals that can function effectively in the technology changing society. According to Sharp and Potter (2002) and Olibie (2003), teaching is becoming one of the most challenging professions in our society where knowledge is expanding rapidly and much of it is available to students as well as teachers at the same time. As new concepts of learning have evolved, teachers are expected to facilitate learning and make it meaningful to individual learners rather than just to provide knowledge and skills. Modern developments of innovative technologies have provided new possibilities to teaching professions but at the same time have placed more demands on teachers to learn how to use these new technologies in their teaching.

The proliferation of information and communication technologies (ICTs) in education has changed the way teachers teach and students learn due to the expanse of activities and advantages associated with it. Briones (2018) indicated that, there are studies that revealed the use of Information and Communication Technology in teaching particularly in Science which indeed enhances students' understanding of scientific facts and ideas. Some of the significant contributions of using ICT in teaching which includes: (a) making students' learning more effective; (b) increasing students' motivation; (c) enhancing students' sense of achievement; (d) providing students with access to richer sources of data and information; (e) helping students to become autonomous learners; (f) reducing pressure on students by letting them work at their own speed; (g) enhancing students' literacy skills; (h) making teachers take a fresh look at the way they teach; and (i) freeing teachers from administration to focus on students' learning. The advent of technology in education has given birth to the application of social media in teaching and learning of science. This has become necessary because Nigerian students in the $21^{\text {st }}$ century are already involved in the use of information and communication technologies through social media in various activities such as connecting with one another on daily basis. The application of social media as an instructional tool, provide an alternative for educators to adopt new approaches for training of science teachers.

Dabbagh and Kitsantas (2012) defined social media as a variety of networked tools or technologies that emphasize the social aspects of the Internet as a channel for communication, collaboration, and creative expression, and is often interchangeable with the terms Web 2.0 and social software. Anderson (2007) noted that Social media are networked tools that support and encourage individuals to learn together while retaining individual control over their time, space, presence, activity, identity and relationship. Bryer and Zavatarro (2011) stated that, Social media are technologies that facilitate social interaction, make possible collaboration, and enable deliberation across stakeholders. These technologies include blogs, wikis, media (audio, photo, video, text) sharing tools, networking platforms (including Facebook), and virtual worlds. Kaplan and Haenlein (2010) opined that, Social Media is a group of Internet-based applications that build on the ideological and technological foundations of Web 2.0, and that allow the 
creation and exchange of User Generated Content. Social media is defined by three elements: content, groups and use of the Internet. Content can include text, pictures or videos published on Internet. Groups are the second important element in social media; they offer ways in which places where people can communicate with each other. The last element is the Internet itself: without the Internet there would be no social media (Mari, Heidi, \& Leena, 2017). Wankel (2010) points out that social media are technologies that bring learners collaboratively together with the world. Some of the social networking media includes Twitter, Yahoo Messenger, WhatsApp, Facebook Messenger, Blackberry Messenger (BBM), 2go messenger, Skype, Google talk, Google Messenger, among others. Laird (2014) stated that Social media and electronic forms of communication encompass a range of formats including social networking, content sharing, and blogging. This form of media is altering communication as it allows online communities of users to contribute, modify, and co-create content. The purpose of social media is to share information and content, exchange ideas, engage in dialogue through comments and personal messages, and create communities.

The introduction of social media in educations helps the students to reach for information any time without being limited by space, it also enhances collaboration and sharing of knowledge. Dalsguard in Okereke (2014) states that the idea of using social media is to provide students with a variety of tools for independent work, reflection, construction and collaboration. Social network also provides learners with value resources for using the web as a tool in order to develop their understanding and solve problems, whether in school, at work, or in their private lives. The dynamic nature of this technology enables users to have an open access to knowledge and contribute local content on the social network space (Okereke \& Ogenetega, 2014). Oghenetega and Ejedafiru (2014) noted that social media have affected communication between people in educational community positively since the past decades, and life is made easy by this media in different areas such as academically, socially, and politically for any that is connected to it. Eke, Omekwu and Odoh (2014) noted the following positive impacts of social media on the academics of students: Web Engagement; Informal Knowledge and Skill; Education; Individual Identity and Self-expression; Strengthening Interpersonal Relationships. Sherer and Shea (2011) stated that social media can be an instructional alternative to get across a teacher's ideas from the very start of classes. It is also a strategy for tracking learning outcomes online. The social media's most distinctive aspect is its potential to transform from pushing content outward to engaging in conversation for actually exchanging information. Peter in Morrison, Oyedele, Oladunjoye and Maman (2017) also found that there is a positive relationship between academic success and use of social media. He thus recommended that utilizing social media in education is helpful for enhancing academic activities, but he also cautioned that students should be monitored by teachers on how they use these sites. Mills (2011) pointed towards the value of social-networking tools for their capacity to attract, motivate and engage faculty in meaningful interactive teaching practices, content exchange, and collaboration. Muhammad, Munir, and Saif-ud-Din (2017) stated that social media increase the collaboration, interaction, learning content and attributes related courses that enhance the effectiveness of teachers in a formal way as well as informal way. It will increase their communication skills and knowledge related to their job work profile. Social media has become an educational tool that creates many advantages for students, teachers and employees and still discovering its advantages. The use of Facebook helped to improve the learning achievements. It also helped to expand students' perspectives and provide them the 
career opportunities in the related subject (Hurt, 2012). According to Arul and Veena (n.d), to be fully prepared to function productively in a technology-oriented society, students must develop not only fundamental computer skills but also proficiency in using a variety of technology tools to solve problems, make informed decisions, and generate new knowledge. The development of these skills, as in other basic areas of knowledge, is the responsibility of the schools and their instructional staff. The need to prepare science education pre-service teachers to fit into the world of technology and education in the 21 st century is the major concern that social media skills must be acquired by them.

The incorporation of social media in education needs to be addressed in teacher education programs as well. Often, there is little attention paid to social media as an educational tool unless teacher candidates take specialized courses on media and technology. Bull, Thompson, Searson, Garofalo, Park, Young and Lee (2008) stated that, as teacher education students graduate and enter schools, they will bring knowledge and understanding of ways in which technology, pedagogy, and content knowledge can be combined. This will only occur if teacher education faculty members serve as effective mentors. Bull et al in Laird (2014) stated that Social media presents new challenges for educators as today's students are increasingly using these new systems and educators should be prepared to work with students who have an information-age mindset. For example, if educators are not aware of these modern forms of social media, it is difficult to understand and teach with using these modern teaching methods. Emphasis should be put on educator's level of engagement with social media use and social media should be a part of educator education qualifications. Although the use of social media in teaching and learning has become inevitable to produce marketable and employable graduates, many teacher training institutions in Nigeria suffer from a lack of application or use of appropriate technologies by lecturers. This may stem from their lack of competence in the application of technological tools in teaching and learning process because educators who are competent in the use of social media for personal purpose utilize them in classroom situation than those who are not competent.

Katane, Aizsila, Beitere (2006) defined competencies as the set of knowledge, skills, and experience necessary for future, which manifests in activities. Gupta (1999) defines competencies as "knowledge, skills, attitudes, values, motivations and beliefs people need in order to be successful in a job. Orji and Abolarin (2012) refer to competence as the effectiveness or ability of anyone concerned to apply the acquired knowledge and skill to achieve desired results. Social media competence is the procession of knowledge, skill and ability to apply different aspects of social media in teaching and learning process. In this instance, the skills and ability of educators to plan and execute their teaching in the classroom utilizing social media platforms determines their competence. Becker (2000) notes that, teachers who have a reasonable amount of technical skill and who use computers to address their own professional needs use computers in broader and more sophisticated ways with students than teachers who have limited technical skills and no personal investment in using computers themselves.

The definitions above therefore, indicate that competence in the use of social media is very much required by educators to be able to utilize them in their teaching considering its importance in the improvement of standard and quality of teaching and learning process and education in general. However, some educators may consider utilization of technologies in the 
classroom as another demand on their time, as they are set of tools they did not ask for and do not know how to use. While some educators may feel they are already doing a good job in the classroom and wonder how utilization of technologies will contribute to improvements. Still other educators support the utilization of technologies such as the social media and are eager to learn how to use them.

\section{Statement of the Problem}

Teachers are central to the effectiveness of utilization of technology infrastructures that serve education. How teachers acquire the skills they need to use technologies and how the technology is actually used and to what ends, are critical policy domains that must be carefully explored.

Based on the foregoing, this study was carried out to determine educators' competence and utilization of social media in trainee science teacher education in Imo State.

\section{Purpose of the Study}

The main purpose of the study was to determine educators' competence and utilization of social media in science teacher education. Specifically, the study investigated:

1. Whether science teacher educators are competent in the use of social media

2. Level of utilization of social media in training science teachers by educators in teacher training institutions.

\section{Research Questions}

The following research questions guided the study

1. To what extent are science teacher educators competent in the use of social media in teachers' training institutions?

2. What is the level of utilization of social media in training science teachers in teacher training institutions?

\section{Methodology}

The study adopted the descriptive survey research design to determine educators' competence and utilization of social media in science teacher education. The population of the study consists of all the one hundred and thirty four (134) science educators in School of Sciences of Alvan Ikoku Federal College of Education, Owerri, Imo State, Nigeria. The entire population was used as sample for the study considering the size. The instrument for data collection was a researcher made likert 4-point type questionnaire titled "Educators Competence and Utilization of Social Media (ECUSM)" which was divided into two sections. Section A consists of respondents' demographic variables while section B consists of items related to the objectives of the study. The item responses ranged as thus; Strongly Agree $(\mathrm{SA})=4$ points, Agree $(\mathrm{A})=3$ points, 
Disagree $(\mathrm{D})=2$ points, Strongly Disagree $(\mathrm{SD})=1$ point. The face and content validity of the instrument were determined by two experts in measurement and evaluation and a science educationist from the same institution. The instrument was subjected to reliability test by administering 30 copies to educators having same characteristics with the intended respondents using test-retest method within two weeks and their responses were analyzed using Pearsons' Product Moments Correlation Coefficient method which gave a reliability coefficient of 0.83 which was acceptable for the study. The instrument was administered to the respondents on faceto-face basis and the respondents were allowed to fill out the instrument and return it on the spot. The entire exercise lasted for two weeks and all instrument distributed was returned. The data generated were analyzed using mean and standard deviation to answer research questions, any response mean within and above the criterion mean of 2.50 was accepted while any below that was rejected.

\section{Result}

Research Question 1: To what extent are science teacher educators competent in the use of social media in teachers' training institutions?

Table 1: Summary of educators' Social media competence

\begin{tabular}{lllll}
\hline S/N & \multicolumn{1}{c}{ Item } & Mean & SD & Remark \\
\hline 1 & $\begin{array}{l}\text { I can send and receive messages through social media } \\
\text { platforms. }\end{array}$ & 3.25 & 0.21 & Accept \\
2 & $\begin{array}{l}\text { I can download academic materials using social media } \\
\text { platforms. }\end{array}$ & 3.03 & 0.82 & \\
3 & $\begin{array}{l}\text { I can share videos and photos using social media } \\
\text { platforms. }\end{array}$ & 2.89 & 0.56 & “ \\
4 & $\begin{array}{l}\text { I can communicate with students and colleagues using } \\
\text { social media platforms. }\end{array}$ & 3.12 & 0.28 & “ \\
5 & $\begin{array}{l}\text { I can source any form of information using social media } \\
\text { platforms. }\end{array}$ & 3.10 & 0.28 & “ \\
6 & $\begin{array}{l}\text { I make contributions on online forums and discussions. } \\
\text { I can share ideas and experiences on social media }\end{array}$ & 2.75 & 1.02 & “ \\
8 & $\begin{array}{l}\text { platforms } \\
\text { I can create and manage profiles on social media }\end{array}$ & 2.65 & 1.00 & “ \\
9 & $\begin{array}{l}\text { I can manipulate different software for various purposes } \\
\text { on social media. }\end{array}$ & 2.85 & 0.55 & “ \\
10 & $\begin{array}{l}\text { I can retrieve or delete information on social media } \\
\text { platforms. }\end{array}$ & 2.59 & 1.23 & “ \\
11 & $\begin{array}{l}\text { I can upload original, visual and textual information on } \\
\text { social media platforms. }\end{array}$ & 3.42 & 0.18 & “ \\
\hline Average & 3,21 & 0.24 & “ \\
\hline
\end{tabular}

Average Mean $=\mathbf{3 . 0 0}$

Table 1, shows that all the items relating to educators' social media competence were accepted as they had response mean greater than the criterion mean of 2.50. Also the average mean of 3.00 is greater than the criterion mean which implies that educators are of moderate competence with regards to social media usage. 
Research Question 2: What is the level of utilization of social media in training science teachers in teacher training institutions?

Table 2: Summary of educators' utilization of social media for teacher training

\begin{tabular}{|c|c|c|c|c|}
\hline $\mathbf{S} / \mathbf{N}$ & Items & Mean & SD & Remark \\
\hline 1 & I use social media platforms to send assignment to my students. & 2.03 & 1.23 & Reject \\
\hline 2 & I share course materials with students using social media platforms. & 2.34 & 1.35 & “ \\
\hline 3 & I make my teaching lively using social media platforms. & 1.58 & 1.50 & “ \\
\hline 4 & $\begin{array}{l}\text { I engage students on classroom activities using social media platforms } \\
\text { such as WhattsApp, Facebook messenger, etc. }\end{array}$ & 1.45 & 1.02 & “ \\
\hline 5 & $\begin{array}{l}\text { I allow students have access to videos/illustrations related to topics } \\
\text { using social media platforms such as YouTube. }\end{array}$ & 2.13 & 1.32 & “ \\
\hline 6 & $\begin{array}{l}\text { I allow students ask questions and get feedbacks using social media } \\
\text { platforms. }\end{array}$ & 2.30 & 1.34 & “ \\
\hline 7 & $\begin{array}{l}\text { I engage my students on academic discussions using social media } \\
\text { platforms. }\end{array}$ & 2.15 & 1.45 & “ \\
\hline 8 & $\begin{array}{l}\text { I use social media platforms to enable my students understand scientific } \\
\text { concepts and expressions. }\end{array}$ & 1.62 & 1.26 & “ \\
\hline 9 & $\begin{array}{l}\text { I allow students engage in collaborative learning in class using social } \\
\text { media platforms }\end{array}$ & 1.59 & 1.51 & “ \\
\hline 10 & $\begin{array}{l}\text { I don't use social media platforms in class because it causes distractions } \\
\text { among students }\end{array}$ & 3.20 & 0.25 & Accept \\
\hline 11 & I teach students using Skype video conferencing & 1.34 & 0.92 & Reject \\
\hline 12 & I allow students present their projects using social media platforms. & 1.33 & 1.02 & “ \\
\hline 13 & Social media platforms makes teaching easy and understandable & 2.22 & 1.33 & “ \\
\hline Av & ge Mean = 2.00 & & & \\
\hline
\end{tabular}

Table 2 shows that only one item was accepted as it had response mean greater than the criterion mean of 2.50. However, twelve other items were rejected as they had response mean less than the criterion mean. Also the average mean of 2.00 is below the criterion mean, this implies that, educators' level of application of social media platforms in teaching trainee teachers is very low.

\section{Discussion}

The study revealed in table 1 that all the items related to the objectives of the study as outlined were accepted as they had response mean greater than the instrument criterion mean. Also the grand mean was also a clear indication that educators are moderately competent with the use of social media platforms for personal purposes such as communications, information, sourcing of academic materials, and other social factors. This result is in agreement with the findings of Hussain (2012) which indicated that faculty of education students used social media for sharing academic learning experiences with other friends at national and international levels and Ezeah, Asogwa and Obiorah (2013) which showed that social media was used for getting entertainment, education/information, to discuss national issues, engage in cyber etc, among Nigerian University students.

Also, the study revealed that, one item on table 2 was accepted as it had response mean greater than the instrument criterion mean, while others were rejected as they had response mean less than the criterion mean. The average mean was also less than the criterion mean which implied that, educators level of utilizing social media platforms for academic purposes for training of 
science trainees teachers is very low. This result is in consonance with the findings of Morrison, Oyedele, Oladunjoye, and Maman (2017) which revealed that Nigerian business teacher educators are hesitant about use of social media for a number of reasons which includes their fear of student abuse of the use of these social media.

\section{Conclusion}

The result of the present study revealed that educators of trainee science teachers are moderately competent on the use of social media platforms, but their level of utilization of these platforms in academic purposes for training of science teachers in teacher training institutions in Nigeria is very low.

\section{Recommendations}

Based on the findings of the study, the following recommendations are made;

1) Science teacher educators should be exposed to the benefits of utilizing social media platforms for academic purposes through conferences, workshops and seminars.

2) Government and NGOs should provide internet facilities to teacher training institutions to enable the educators utilize them in the training of their trainee teachers.

3) The curriculum planners should emphasize the utilization of social media platforms by educators as an alternative to face-to-face contact and equip trainee teachers for the task ahead in their teaching profession. 


\section{Reference}

Anderson, P. (2007). What is Web 2.0? Ideas, technologies and implications for education. H.S.C. JISC Technology and Standards Watch, Feb. 2007

Arul, L.A. \& Veena, K.S.(n.d).Improving teacher competency through ICT. Retrieved from https://www.academia.edu/1276235/ict_and_teacher_competencieson 26th match 2020

Becker, H. J. (2000) Findings from the Teaching, Learning, and Computing Survey: Is Larry Cuban Right? Education Policy Analysis Archives, 51, 8

Briones, C. B. (2018).Teachers' Competency on the Use of ICT in Teaching Physics in the Junior High School. KnE Social Sciences / 4th International Research Conference on Higher Education,pg 177-204.

Bryer, T. \& Zavattaro, S. (2011). Social media and public administration: Theoretical dimensions and introduction to symposium. Administrative Theory \& Praxis, 33(3),

Bull, G., Thompson, A., Searson, M., Garofalo, J., Park, J., Young, C., \& Lee, J (2008). Connecting informal and formal learning: Experiences in the age of participatory media. Contemporary Issues in Technology and Teacher Education, 8, 100-107.

Dabbagh, N., \& Kitsantas, A. (2012). Personal Learning Environments, social media, and selfregulated learning: A natural formula for connecting formal and informal learning. Internet and Higher Education, 15, 3-8. doi: 10.1016/j.heduc.2011.06.002

Eke,H. N., Omekwu,C.S \& Odoh, J.N. (2014). The Use of Social Networking Sites among the Undergraduate Students of University of Nigeria, Nsukka. Library Philosophy and Practice (e-Journal), paper 1195 325-340.

Ezeah, G. H., Ph, D., Asogwa, C. E., \& Obiorah, I. (2013). Social media use among students of universities in South-East Nigeria. IOSR Journal Of Humanities And Social Science (IOSR-JHSS)16(3), 23-32

Gupta, K.(1999). A practical guide for need assessment. San Francisco: John Wiley \& Sons. Inc. http://www.globaleducators.org.

Hussain, I. (2012). A study to evaluate the social media trends among university students. Procedia - Social and Behavioural Sciences, 64, 639-645.

Kaplan, A. M., \& Haenlein, M. (2010). Users of the world, unite! The challenges and opportunities of social media. Business Horizons, 53, 59-68. doi: 10.1016/j.bushor.2009.09.003 
Katane, I., Aizsila, A.; Beitere, Z. (2006). Teacher competence and further education as priorities for sustainable development of rural school in Latvia. Journal of Teacher Education and Training. 6.:41-59.

Laird, T. (2014). Using social media in education for classroom teaching, student learning, and educator professional development. M.Ed thesis Queen's University Kingston, Ontario, Canada

Mari, L. Heidi, H. \& Leena, S.(2017).Use of Social Media By Nurse Educator Students: An Exploratory Survey. Open Nursing Journal 11: 26-33.

Mills, N. (2011). Situated Learning through Social Networking Communities: The Development of Joint Enterprise, Mutual Engagement, and a Shared Repertoire. CALICO dimensions and introduction to symposium. Administrative Theory \& Praxis, 33(3),

Morrison, J.L., Oyedele,J., Oladunjoye, G.T. \& Maman, J. (2017). The utilization of social Media in the classroom by business teacher educators in Nigeria. Africa Journal of Teacher Education 6(1) 22-38.

Muhammad, I.K., Munir, A. \& Saif-ud-Din, A.A.(2017) The impact of social media on teacher's performance: A Case of Higher Educational Institutions of Pakistan. European Online Journal of Natural and Social Science 6(2), 206-221.

Oghenetega L.U. and Ejedafiru E.F (2014). Librarians and Social media as catalyst for national development in Nigeria (forthcoming) Library Philosophy and Practice(e-journal)

Okereke, E. (2014). Awareness, competencies and use of social media in teaching by lecturers in higher institutions in South -East Of Nigeria. European Journal of Business and Management6, (36), 149-154

Okereke, E.C. \& Ogenetega, L.U.(2014). The impact of social media on the academic performance of University Students in Nigeria. Journal of Education and Practice 5(33), 21-24.

Olibie, E. (2003). Effects of Computer-Assisted Language Learning on Students' Achievement in English Language. Ph.D Thesis Submitted to Faculty of Education Nnamdi Azikiwe University, Awaka.

Orji, U. E., \& Abolarin, E. (2012). Strategies for enhancing teacher competence and quality of classrooms instruction. Global Voice of Educators, 1(1),1-6. http://www.globaleducators.org.

Sharp, J. and Potter, J. (2002). Primary ICT: Knowledge, understanding and practice, $2^{\text {nd }}$ edition. Glasgow: Learning Matters Ltd. 
International Journal of Advanced Academic Research (Arts, Humanities and Education) | ISSN: 2488-9849

Vol. 6, Issue 8 (August, 2020)|www.ijaar.org

Journal DOI: 10.46654/ij.24889849

Article DOI: 10.46654/ij.24889849.a688

Sherer, P. \& Shea, T. (2011) Using Online Video to Support Student Learning and Engagement. Journal of College Teaching, 59(2), 56-59. DOI: 10.1080/87567555.2010.511313.

Wankel, C. (2010). Cutting-edge social media approaches to business education. A volume in the series: Research in Management Education and Development 6(2), 206-221. 